\title{
Storage Period, Husking and Seed Treatment Effects on Germination of Rhodes Grass (Chloris gayana L.) Seeds
}

\author{
Karta K. Kalsa ${ }^{1^{*}}$, Tesfaye Geleta ${ }^{2}$ and Diriba Geleti ${ }^{2}$ \\ ${ }^{1}$ Kulumsa Agricultural Research Center, P.O. Box: 489, Asella, Ethiopia \\ ${ }^{2}$ Debrezeit Agricultural Research Center, P.O. Box: 32, Bishoftu, Ethiopia
}

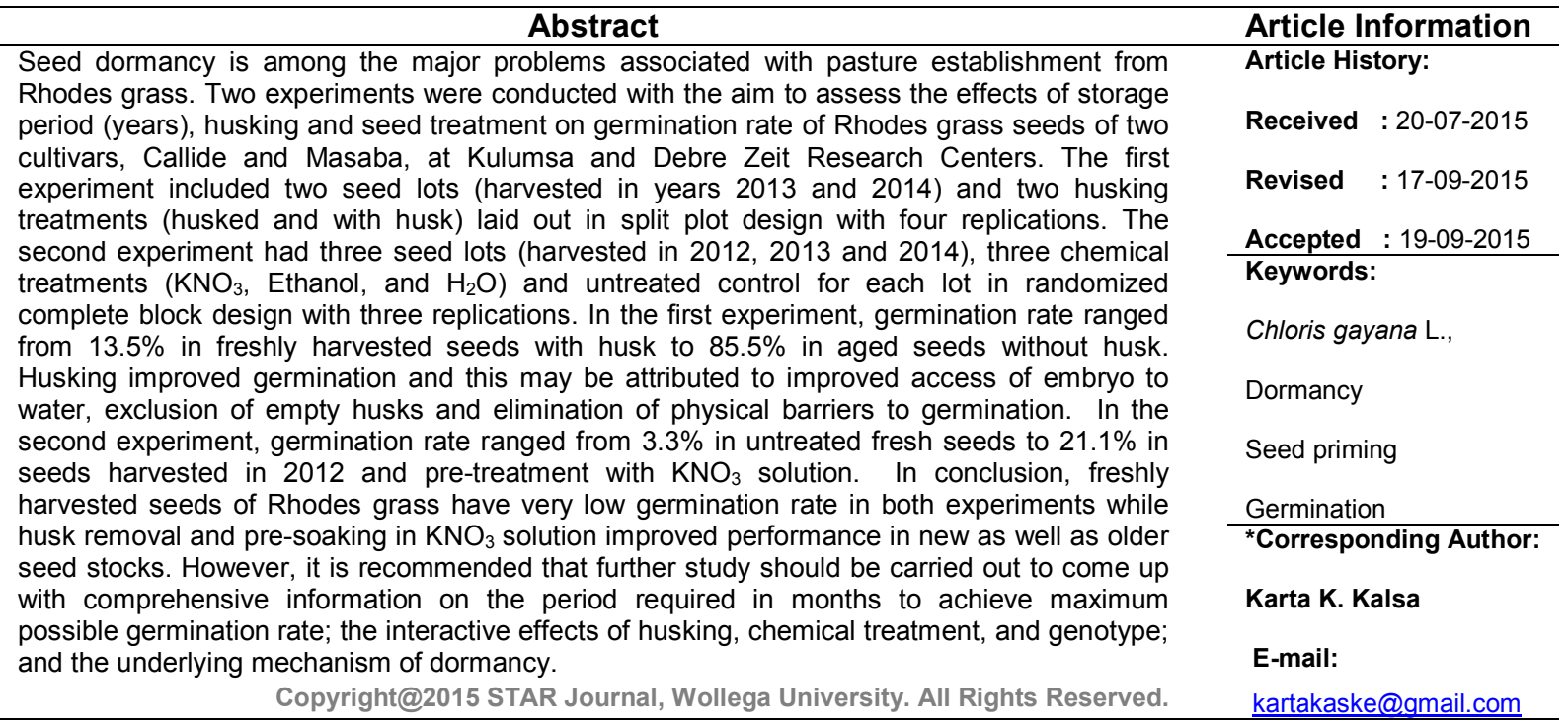

\section{INTRODUCTION}

Rhodes grass (Chloris gayana L.) is among the mostly used pasture grass species in Ethiopia. It can be established as sole pasture or in mixture with herbaceous legumes (Solomon Mengistu, 2008). Seed dormancy is among the major problems associated with pasture establishment from tropical grasses including Rhodes grass (Shanmugavalli et al., 2007). In tropical herbage grasses such as Rhodes grass, the seed dormancy characteristics have not been substantially altered by plant breeders (Adkins et al., 2002). The natural persistence of such species depends on their ability to reseed and their dormancy strategy (Pistorale, S., 1999). Freshly harvested seed of Rhodes grass may require post-harvest storage period up to six months before achieving adequate germination for pasture establishment (Cook, et al., 2005).

Type of seed treatment to break dormancy depends on the mechanism of dormancy: mechanisms based within the embryo covering structures, and mechanisms based within the embryo (Bewley, 1997). Mechanisms within the covering structures may involve mechanical, permeability and chemical barriers to germination whereas mechanisms within the embryo may involve the expression of certain genes, levels of certain plant growth regulators, the activity of important respiratory pathways or the mobilization and utilization of food reserves (Adkins et al., 2002). It is well documented that certain tropical and sub-tropical grass species have positive response to post-harvest storage until certain period of time (Kawonga, 1997). Besides, seed treatment methods such as acid-digestion (Stevens et al., 2015) and soaking in $\mathrm{KNO}_{3}$ solution or priming in water (Nichols et al., 2012) are also recommended to alleviate dormancy problems in grasses. The present study was initiated with the aim to assess the effects of storage period (years) and seed treatment on germination rate of Rhodes grass seeds.

\section{MATERIALS AND METHODS}

Two experiments were conducted to understand the effects of seed storage period, husking and chemical treatment on germination characteristics of Rhodes grass. The first experiment was conducted using Rhodes grass cv. Callide at Kulumsa Agricultural Research Center. Seed stocks produced and harvested at Kulumsa in December 2013 and 2014 were used for the experiment. Working samples were prepared based on the prescribed standards. The submitted sample of $1000 \mathrm{~g}$ from each seed stock was used as working sample (ESA, 2012). 
Karta K. Kalsa et al.,

The working sample was further divided into two portions and $50 \mathrm{~g}$ was taken from each portion to conduct the germination test with or without husks. The seed stocks (2013 and 2014 harvests) were considered as main plot factor while the husking treatments (husked and with husk) were used as sub-plot factor. Hundred seeds were sown on top of a $150 \mathrm{~mm}$ blotter paper saturated with distilled water per replicate and placed in plastic bowels. The bowels, then, were placed at room temperature for 14 days and germination was recorded based on normally germinated seeds.

The second experiment was conducted using cv Masaba at Debre Zeit Agricultural Research Center. Seed stocks harvested at Debre Zeit in December 2012, 2013 and 2014 were used for the experiment. Chemical treatments used were $2 \% \mathrm{KNO}_{3}, 50 \mathrm{ppm}$ Ethanol and distilled water $\left(\mathrm{H}_{2} \mathrm{O}\right)$. The seeds were soaked in the chemical treatments for 24 hours and dried back to the normal moisture content before germination test. The $3 \times 4$ factorial treatment combinations were laid out in randomized complete block design with three replications. Analysis of variance and mean separation was carried out using the R-software packages. Percentage data were log transformed before subject to analysis of variance while mean separation was carried out on the percentage data at $5 \%$ level of probability.

\section{RESULTS AND DISCUSSION}

\section{Experiment I}

Results from the analysis of variance on transformed germination data for the effects of storage period, husking treatment and their interaction is presented in Table 1. The effect of storage period, husking and their interaction was highly significant $(p<.001)$. Germination performance of seed from storage periods was significantly dependent on use of husked seed or seed with husk.

Table 1: Analysis of variance on effect of husking and seed age on seed germination of Rhodes grass cv. Callide harvested in different years at Kulumsa

\begin{tabular}{|c|c|c|c|}
\hline Source of variation & $\begin{array}{l}\text { Degree of } \\
\text { Freedom }\end{array}$ & $\begin{array}{c}\text { Mean } \\
\text { Squares }\end{array}$ & $p$ level \\
\hline Replication & 3 & 0.0023 & NS \\
\hline Year of Harvest (Y) & 1 & 0.2256 & $* * *$ \\
\hline Error a & 3 & 0.0056 & \\
\hline Husking $(\mathrm{H})$ & 1 & 1.2656 & $* * *$ \\
\hline $\mathrm{Y} \times \mathrm{H}$ & 1 & 0.1806 & $* * *$ \\
\hline Error b & 6 & 0.0031 & \\
\hline
\end{tabular}

Germination rate ranged from 13.5 on freshly harvested seeds with husk to $85.5 \%$ on aged seeds without husk. Germination percent was generally low for seeds with husks in either of seed ages. However, higher mean germination rates were recorded by removing husks, the values being close to 86 and $75 \%$, for seed stocks of 2013 and 2014, respectively. Though husk removal improved germination performance, it had better effect on the older stocks. Improvement in germination performance of Rhodes grass seeds on husked seeds might be attributed to different factors such as enhanced access of the caryopsis to moisture, exclusion of empty husks from the germination test, and removal of physical barrier. Previous studies indicated that the main
Sci. Technol. Arts Res. J., July-Sep 2015, 4(3): 58-60

mechanisms of glumes were the mechanical resistance of glumes (Ma et al., 2010). Therefore, seed quality testing laboratories need to consider husk removal treatment before germination tests are conducted.

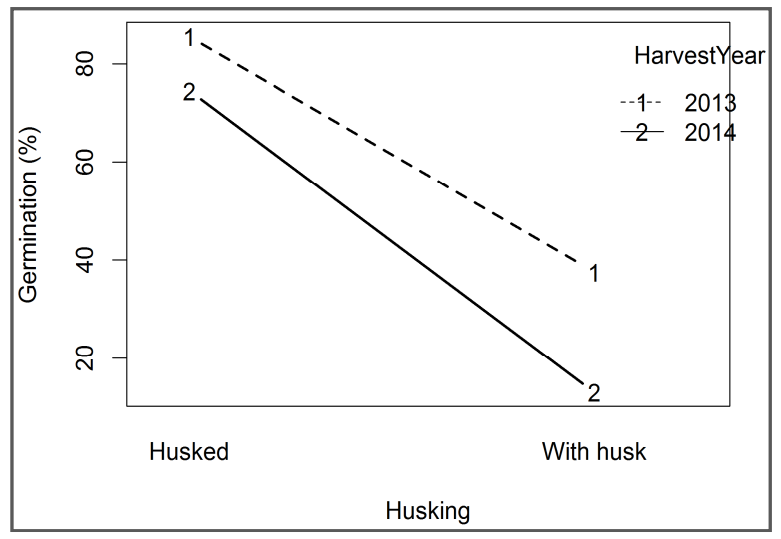

Figure 1: Germination performance of Rhodes grass seed stocks with and without husks. LSD $=5.6$ $(0.11) \%$, where number in parenthesis is for transformed data

\section{Experiment II}

The second experiment was conduction on $\mathrm{cV}$ Massaba, produced and harvested at Debre Zeit Agricultural Research Center. Chemical treatments were applied on seeds with husk. Analysis of variance indicated that the statistically significant main effects of chemical treatment and duration of storage $(p \leq 0.001)$ on germination rate (Table 2). The effect of the interaction of the two factors was also significant $(p \leq 0.01)$.

Table 2: Analysis of variance for the effects of chemical treatment of Rhodes grass seeds harvested in different years at Debre Zeit

\begin{tabular}{|c|c|c|c|}
\hline $\begin{array}{l}\text { Source of } \\
\text { variation }\end{array}$ & $\begin{array}{l}\text { Degrees of } \\
\text { Freedom }\end{array}$ & $\begin{array}{c}\text { Mean } \\
\text { Squares }\end{array}$ & $p$ level \\
\hline Replication & 2 & 4.95 & \\
\hline Treatment & 3 & 115.18 & *** \\
\hline Year & 2 & 152.26 & $* * *$ \\
\hline Treatment xYear & 6 & 22.77 & ** \\
\hline Residuals & 22 & 4.55 & \\
\hline
\end{tabular}

Seed germination rate (\%) was positively associated with seed age. Regardless of seed treatment, older seed lots demonstrated relatively better germination than that of freshly harvested ones (Figure 2). Germination rate mean values for treated seeds were lower for freshly harvested seeds than aged ones. However, priming (pre-soaking) in $\mathrm{KNO}_{3}$ solution significantly $(p<0.05)$ improved germination rate of seeds, values ranging from $11.6 \%$ for 2014 to $21.1 \%$ for 2012 , as compared to the untreated controls. These findings are in conformity with previous reports on the post-harvest storage requirements of Rhodes grass seeds to achieve maximum germination (Kawonga, 1997). However, the findings in Experiment I indicated that the germination percentage might be higher if the husks were removed and chemical treatments were applied (Ma et al., 2010) on naked caryopses. 
Karta K. Kalsa et al.,

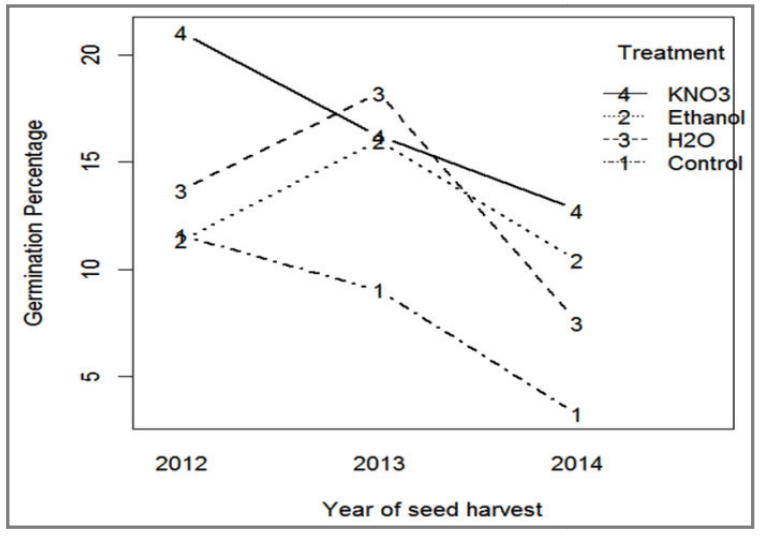

Figure 2: Effects of chemical treatment on germination percentage of Rhodes grass seeds harvested in different years at Debre Zeit. LSD (0.05)= $3.13 \%$

\section{CONCLUSIONS}

Germination performance of Rhodes grass seeds ranged from $3 \%$ to above $85 \%$ depending on seed age, husking and chemical treatment application. Freshly harvested seeds of Rhodes grass had low germination rate as compared to that of aged ones. Husk removal might have improved germination by improving access of the embryo to water, excluding empty husks and eliminating physical barriers for germination. Pretreatment with $\mathrm{KNO}_{3}$ has enhanced seed germination but, removal of husks in combination with chemical pretreatment might have better effect.

The present study has some limitations that further investigations need be carried out. The experiments were conducted on seeds harvested in separate years and do not show the required period of storage in months for maximum germination. It also has deficiency in indicating the combined influence of husking, chemical treatment, and genotypes on germination rate. Moreover, the prevailing dormancy mechanism (whether it is purely after-ripening requirement or combined with mechanical barrier) is also vaguely understood. Therefore, it is recommended that further study should be carried out to come up with comprehensive information on the period required in months to achieve maximum possible germination rate; the interactive effects of husking, chemical treatment, and genotype; and the underlying mechanism of dormancy.
Sci. Technol. Arts Res. J., July-Sep 2015, 4(3): 58-60

\section{Conflict of Interest}

Conflict of interest none declared

\section{REFERENCES}

Adkins, S.W., Bellairs, S.M. and Loch, D.S.( 2002). Seed dormancy mechanisms in warm season grass species. Euphytica 126(1): 13-20.

Bewley, J. (1997). Seed Germination and Dormancy. The Plant Cell 9(7): 1055-1066.

Cook, B.G., Pengelly, B.C., Brown, S.D., Donnelly, J.L., Eagles, D.A. and Hanson, J. (2005). Tropical Forages: An interactive selection tool. Available at www.eerf.com (verified 24 July 2015).

ESA. (2012). ETHIOPIAN STANDARDS: Seed-Sampling. Ethiopian Standards Agency (ES471:2000): 1-9.

Kawonga, K.C. (1997). The effects of storage period on the germinability of Rhodes grass (Chloris gayana). p. 1920. In: Proceedings XVIII I. World Grassland Congress, Winnepeg, Manitoba

Ma, H.Y., Liang, Z.W., Liu, M., Wang, M.M. and Wang, S.H. (2010). Mechanism of the glumes in inhibiting seed germination of Leymus chinensis (Trin.) Tzvel. (Poaceae). Seed Science and Technology 38(3): 655-664.

Nichols, P.G.H., Yates, R.J., Loo, C., Wintle, B.J., Titterington, J.W., Stevens, J.C. and Dixon, K.W. (2012). Establishment of sub-tropical perennial grasses in southwestern. Future Farm Industries CRC Technical Report 9. Published by Future Farm Industries CRC. The University of Western Australia.

Pistorale, S., Wolff, R. and Bazzigalupi, O. (1999). Dormancy and seed germination in natural populations of Bromus catharticus Vahl (Cebadilla criolla). Journal of Gentics and Breeding 53: 47-55.

Shanmugavalli, M., Renganayaki, P.R. and Menaka, C. (2007). Seed dormancy and germination improvement treatments. SAT eJournal 3(1): 1-3.

Solomon Mengistu. (2008). Forage Development for Sheep and Goats. p. 161-209. In: Yami, A., Merkel, R.C. (eds.), Sheep and Goat Production Handbook for Ethiopia. Ethiopia Sheep and Goat Productivity Improvement Program (ESGPIP), Addis Ababa.

Stevens, J., Chivers, I., Symons, D. and. Dixon, K. (2015). Acid-digestion improves native grass seed handling and germination. Seed Science and Technology 43(2): 313317. 